\title{
CONTRIBUTION OF BANJAR ULAMA IN THE DEVELOPMENT OF ISLAMIC EDUCATION IN SAMARINDA CITY
}

\author{
Khojir \\ Fakultas Tarbiyah dan Keguruan, UIN Samarinda \\ Jalan H.A.M. Rifaddin, Kampus 2 Loa Janan Ilir Samarinda \\ Email: khojir@iain-samarinda.ac.id
}

\begin{abstract}
:
Samarinda is a multi-ethnic city, and there are various urban Ulama in Samarinda such as Javanese, Banjar, Bugis, and Madurese Ulama. Urban Ulama has made a significant contribution to the development of Islam. This research specifically examined the contribution of Banjar Ulama in the development of Islamic education. The purpose of this article was to determine the contribution of Banjar Ulama to Islamic Education in Samarinda City. This research used a qualitative study with a historical-phenomenological approach. The data sources were from Banjar figures, Paguyuban Banjar, and Banjar Ulama and data collection procedures were done through in-depth interviews and documentation. Data were analyzed using qualitative analysis, namely data reduction, presentation and concluding. The results showed that Banjar Ulama contributed to the development of Islamic education in Samarinda City. The contribution was 1) establishing various types of Majelis Ta'lim in various cities of Samarinda; 2) functioning the mosque as a community education centre (congregation); 3) establishing formal education in madrasah and Islamic universities; 4) founding the first Islamic boarding school in Samarinda; 5) writing books as a reference in providing material in Majelis Ta'lim and the general public. Therefore, the results of this research were the evidence that the Banjar Ulama contributed in real terms to the development of education in Samarinda City.
\end{abstract}

\begin{abstract}
Abstrak:
Samarinda merupakan kota multi etnis dan terdapat berbagai Ulama urban di Samarinda seperti Ulama Jawa, Banjar, Bugis, Madura. Ulama urban mempunyai kontribusi yang signifikan dalam pengembangan Islam. Penelitian ini secara khusus mengkaji kontribusi Ulama Banjar dalam pengembangan Pendidikan Islam. Tujuan penulisan artikel ini adalah untuk mengetahui kontribusi Ulama Banjar dalam Pendidikan Islam di Kota Samarinda. Jenis penelitian ini adalah penelitian kualitatif dengan pendekatan historis-fenomenologis. Sumber data digali dari para tokoh Banjar, Paguyuban Banjar, dan Ulama keturanan Banjar. Metode penggalian data yaitu wawancara mendalam dan dokumentasi. Analisis data menggunakan analisis kualitatif yaitu reduksi data, penyajian dan penarikan kesmpulan. Hasil penelitian menunjukkan bahwa Ulama Banjar berkontribusi pada pengembangan pendidikan Islam di Kota Samarinda. Bentuk kontribusinya yaitu 1) mendirikan berbagai jenis mejelis Ta'lim diberbagai kota Samarinda; 2) memfungsikan masjid sebagai pusat pendidikan masyarakat (jamaah); 3) mendirikan Pendidikan formal berupa madrasah dan perguruan tinggi Islam; 4) mendirikan pesantren pertama di Samarinda; 5) menulis kitab sebagai referensi dalam memberikan materi dalam Majelis Ta'limmaupun masyarakat umum. Dengan hasi penelitian tersebut membuktikan bahwa Ulama Banjar berkontribusi secara riil pada pengembangan Pendidikan di Kota Samarinda.
\end{abstract}




\section{Keywords: \\ Contribution, Banjar Ulama, Islamic Education.}

How to Cite: Khojir (2020). Contribution of Banjar Ulama in The Development of Islamic Education in Samarinda City. Lentera Pendidikan : Jurnal Ilmu Tarbiyah dan Keguruan, 23(2), 247259. https://doi.org/10.24252/lp.2020v23n2i5.

\section{INTRODUCTION}

The Ulama are the successors of the prophet. The position of the Ulama in the theological perspective has very strong legitimacy, having a very high degree in the Qur'an (Arnawati, 2017). Ulama plays a very important role in life, even being one of the reform agents who are, socially constructed, often involved in the reform agenda (Bein, 2012). Ulama also has a role and contribution to urban society (Abidin, 2018). Therefore, their existence has a very strategic role in socio-religious life.

The study of Ulama is very dynamic, namely following the dynamics of life because Ulama exists and contributes to all lines of life. That the reason why the study of Ulama varies. The first is related to Islamic law, such as research conducted by Basyari Fathurrahman (Basyari, 2018). The second is the study of Ulama relating to hadith (Alamsyah, Mahmudah, \& Huda, 2020; Nur, 2013). The third relates to Qur'an and its interpretation as practised by Syahrir Jafaraa (Djafaara, 2020). The fourth is their relations with politics as practised by Leni Winarni (Winarni, 2014). Not only scientific issues, but their studies have developed into Islamic issues in general (A'la, Mukarrom, Zamzami, 2018), and even to the study of Ulama involvement in the arts (Akmaliah, 2014).

The study of Banjar Ulama is not new. There are quite several articles that examine the Banjar Ulama with several variations. First, a study conducted by Mujiburrahman about charismatic Ulama in the contemporary era who have a central role, namely Guru Bakiet, Guru Danau and Guru Zuhdi. The three of them have great magnets so that they can attract the sympathy of the congregation even though they have different educational and social backgrounds (Mujiburrahman \& Abidin, 2012). Second, the study conducted by Iderus on the tradition of writing hadiths from the Banjar Ulama (Iderus, 2016), and the history of hadith studies (Hanafi, 2017). Third, the role of Banjar Ulama in community assistance and development (Makmur, 2012). Fourth, regarding marriage and the problem of polygamy (Helim, 2017). The fifth is the problem of the relation between the jurisprudence book and the environmental issues (Sukarni, 2015). Those four variations at least prove that Banjar Ulama has a significant contribution to life.

In the field of education, Banjar Ulama also plays a strategic role. Based on Yusliani Nur's study that to balance the swift flow of Dutch education, Kasyful Anwar as a Banjar Ulama collaborated with a merchant named Setta to establish Pesantren Darussalam Martapura (Y. Noor \& Sayyidati, 2018). Next, Zaenap Hartati, examined Abraham's role in the fields of da'wah and education. In her study, Zaenap Hartati described that Abraham 
had a very central role in da'wah and education. As a scholar of South Kalimantan, he expanded his preaching wings and founded Islamic educational institutions (pesantren) in Central Kalimantan. Not only in his da'wah and educational activities but also Ibrahim as a writer, especially in writing related to learning material in Islamic boarding schools, in a book called Hidayatul Insan fi Ta'limiddin Tauhid (Hartati, 2012). The study suggests that Banjar Ulama not only play a role and contribute in their region, but also contribute in other areas, even to foreign countries.

Researchers have never conducted studies on the contribution of Banjar Ulama in Samarinda, especially in the field of education as far as the author's search, the author only finds studies of the Banjar descent Ulama. For example, a study conducted by Siti Julaihah focused on the role of Banjar Ulama in the field of da'wah (Julaiha, 2016).

In the previous study, the contribution of Banjar Ulama to education was only limited to local studies and had not touched many other areas and regions. However, the scientific reputation of Banjar Ulama in academic studies is not in doubt with its icon Muhammad Arsyad al-Banjari. Moreover, the next generation in the field of da'wah, especially Majelis Ta'lim, has the influence across provinces and even to several countries. So naturally, the reputation of Banjar Ulama is better known in the field of da'wah through Majelis Ta'lim as practised by Guru Zaini Ghani or better known as Guru Sekumpul.

As the successors of the Prophet, Ulama carry out a very heavy and principled task, responsibility and mandate (Akmal, 2018). The duties of Ulama as explained by Abdullah Satar are to convey Islamic teachings (tabligh), to explain Islamic teachings, to decide cases based on Qur'an verses, and to provide examples (uswah hasanah) (Sattar, 2014). Based on this task, the life of the Ulama should cover all aspects of life. Herein lies the strategic position of writing articles in the development of Islamic education, especially in Samarinda City.

\section{RESEARCH METHOD}

This research was a qualitative description with a historical-phenomenological approach. The focus of this research was the contribution of Banjar Ulama who migrated to Samarinda between 1800-1930, namely Tayyib Babussalam, Abdul Khalid, Abdullah Marisi, Abul Hasan Ja'far Sabran and Asli Husaini. The source of the data was collected from the figures (tetuha) of Banjar, the Banjar Bubuhan Association management and Ulama of Banjar descent. Data collection techniques used were interviews (in-depth interviews), and documentation. Data analysis used was qualitative analysis, namely reduction, presentation and concluding. Testing the validity of data was by using triangulation and Focus Group Discussion (FGD).

\section{RESULTS AND DISCUSSION}

Before discussing the contribution of the Banjar Ulama, first, we needed to discuss the Islamization of the Kutai Kartanegara kingdom briefly. The development of Islam in Samarinda City could not be separated from the Islamization process of the Kutai 
Kartanegara Kingdom. The Islamization of the Kutai Kartanegara Kingdom began around $1607 \mathrm{AD}$, based on Samsir's research that the Islamization of the Kutai Kartanegra Kingdom occurred in 1607 AD, under the work of Ulama from Sumatra, namely Datuk Ri Bandang and Pangeran Tunggang Parangan (Samsir, 2019). Even politically, Pangeran Tunggang Parangan became the king's advisor in formulating policies related to religion (Khaerani, 2015). Also, the existence of Islam in the kingdom of Kutai Kartanegara had a very positive influence on the development of Islam in the kingdom and society, to culture, customs and architecture (Gusmawati, 2015).

Islam became the official religion of the Kutai Kartanegara Kingdom during the reign of Aji Raja Mahkota Mulia. This Islamization had important meaning and had a very broad impact on the development of Islam in the territory of Kutai Kartanegara's work, including Samarinda City. It could not be separated from the role of the king who contributed to the spread of Islam, including in Samarinda City (M. F. Noor, 2016).

The birth and development of Samarinda City could not be separated from the contribution of La Mohan Daeng Mangkona, a noble from the Wajo kingdom who asked for protection from Raja Kutai (Pangeran Adi Pati Mojo Kesuma). In 1668 AD, La Mohan Daeng Mangkona and his troops begged the king to stay in the kingdom because Dutch troops were chasing them. With his great heart, the king allowed them to stay with a requirement that La Mohan Daeng Mangkona and his troops fight against the Solok Philippines pirates who often disturbed the estuary area of the Mahakam River. This requirement was fulfilled, and finally, the king gave the land in Samarinda Seberang to be managed autonomously (As' ad, 2016). At that time, the spread of Islam was limited to the royal court.

The second generation of the spread of Islam in Samarinda was carried out by Sayyid Abdurrahman As-Segaf (Ulama and merchant from Pontianak). With the kindness of the king of Kutai (Aji Muhammad Sultan Sulaiman) Sayyid Abdurrahman Assegaf was allowed to develop da'wah in the Samarinda Seberang area which became the autonomous region of La Mohang Daeng Mangkona. Subsequently, Sayyid Abdurrahman was appointed the Head of Customs and Religion with the title Pangeran Bendahara (Tasa, 2010). One of the Prince Bendahara's contributions was to establish the Shirathal Mustaqiem Mosque in 1881 AD which is the oldest mosque in Samarinda.

Banjar Ulama carried out the third generation of the spread of Islam in Samarinda from Banjarmasin, South Kalimantan between 1800-1930 AD. Among these Ulama, namely Tayyib Babussalam, Abdul Khalid, Abdullah Marisie, Ja'far Sabran. These Banjar Ulama have contributed greatly to the spread of Islam and education in Samarinda City.

Observing the source of the spread of Islamic teachings in Samarinda, there are three currents, namely the Makassar-Sulawesi current, the Pontianak (West Kalimantan) current and the South Kalimantan, Banjarmasin current. Recently, the Banjarmasin flow has more colour in its religious and Islamic education styles compared to the two previous styles. It is because geographically Samarinda-East Kalimantan is directly adjacent to South Kalimantan. So that many Banjarmasin residents who moved to Samarinda with the motive of economic development and preaching by identifying 
themselves with the Banjar Ulama. Besides, the preaching of Banjar Ulama is more concentrated on the community.

Based on literature searches and supported by interviews that Toyib Babussalam was the first generation of Ulama who moved to Samarinda, namely in 1880 AD. Of course, because he was a newcomer, he did not have a place to live, so he decided to live in the mosque near the Mahakam river together with other people from Banjar. As a scholar, his charisma began to appear in the eyes of the community, especially the Banjar people who moved to Samarinda, so that Tayyib Babussalam was appointed as a leader (tetuha) of the Banjar tribe.

In the eyes of the Dutch, Tayyib Babussalam received his sympathy. In 1915, the Dutch government appointed Toyib Babussalam to be the first ruler in Samarinda. Also, he was appointed as the Landrad leader of the Islamic Religion. Because of his reputation, Tayyib Babussalam was given the title Tumenggung Mas Pengulu.

As a religious elite, Tayyib Babussalam began to move the community through socio-religious activities such as Majelis Ta'lim. The activities of Majelis Ta'lim were not limited to mosques, but also door-to-door rotation. Through an alternative educational institution in the form of a council, Tayyib Babussalam educated the public. On the other hand, the Majelis Ta'lim, which was established by Tayyib Babussalam was able to strengthen harmony, especially the Banjar tribe, as a place of change. It was in line with what Amatul Jadidah conveyed that the function of Majelis Ta'lim was as a centre of harmony, change, communication and information, cadre, and social control (Jadidah, 2016).

To strengthen the community development program, Tayyib Babussalam took the initiative to build a mosque together with several other figures. Finally, in 1919 AD, Tayyib founded the Jami' Mosque of Samarinda, located near the Mahakam River. The riverbank was chosen because the river at that time was the main route of transportation. The location was also chosen near the Pasar Pagi meant Morning Market with the consideration that traders and buyers could make the mosque prosperous. In its further development, the mosque became the Darussalam Great Mosque which had a very important role, not only as a centre of worship but also a fairly broad role, namely as a centre for education, preaching and health. It was according to Fathurrahman's research results that the function of mosques was very broad, namely as a centre for education, preaching, community empowerment and the preservation of Islamic culture (Fathurrahman, 2015). Furthermore, Alean al-Krenawi elaborated that the function of mosques starts from the centre of worship to the resolution of social conflicts, family and even political issues (Al-Krenawi, 2016).

Looking at the data above, Tayyib Babussalam was the opening of the Banjar Ulama who has a real contribution to Islamic education, namely establishing a non-formal alternative Islamic education in the form of Majelis Ta'lim as a centre for education, preaching and preserving Islamic culture. Although at that time still under colonial pressure, this did not dampen Tayyib Babussalam's enthusiasm in educating the public. 
The next generation of Banjar Ulama who contributed to Samarinda City was Abdul Khalid. There were no adequate sources about the biography of Abdul Khalid, and it was very limited. Based on documents held by the Great Mosque that Abdul Khalid moved to Samarinda in 1885 AD. Following other Ulama, Abdul Khalid's activities followed in the footsteps of Tayyib Babussalam becoming the imam of the mosque, and was active in filling recitations at the mosque, mushalla, and houses, including his own house. It was a common symptom in several regions, including Sumatra that Islamic education activities in the early 19th century were still centred on mosques, mushalla, langgar, and houses (Rozali, 2017).

When Tayyib Babussalam returned to work as a cleric, Abdul Khalid took over as Landrad Chairman of the Islamic Religion who was appointed by the Dutch Government in 1924. Thus, Abdul Khalid was known as cleric II. On the other hand, Abdul Khalid's attitude of istiqamah, sincerity and high responsibility in educating the public was one of the contributions that could not be ignored so that learning activities could be carried out properly. It was in line with Ulama of national calibre who also have a contribution both in educational activities and attitudes that should be emulated in the next generation, as exemplified by Kholil Bangkalan (Awaluddin, 2020). Based on Hasnida's research results, there were three systems in the education system during the Dutch colonial period, namely the transitional system from Hindu-Islam with the palace and ascetic systems, the surau educational system, and the pesantren educational system (Hasnida, 2017). In this context, the development of Islamic education in Samarinda began the second system, which was still relying on mosques and surau.

The next Banjar Ulama who contributed to education in Samarinda was Abul Hasan. He was born in 1858 AD in the Durian River, Amuntai South Kalimantan. In his youth, Abul Hasan actively participated in non-formal education activities because, at that time, there was no formal institution. After completing the haj pilgrimage at the age of 23, he moved and settled in the Muara Kedang or Bongan Kutai area. However, in 1920, Abul Hasan moved to Samarinda and settled in Gang Haji.

In a short time, Abul Hasan was appointed as Abdul Khalid's closest assistant. Thanks to his diligence in helping Abdul Khalid, leading him to become the leader and khadim at the Landrad of Islamic Religion in Samarinda (e.i. Penghulu III) in 1926 AD. In the same year, assisted by Abdullah Marisie, Abul Hasan founded Madrasah Ahlussunnah School which received a warm welcome from the Samarinda community.

In 1930, Abul Hasan and his family left for Mecca to perform the pilgrimage as well as study with Sheikh Sayed Gusti and other teachers. Before leaving for Mecca, he ordered Abdullah Marisie to replace his position as Landrad of Islam and the government approved the proposal. He died in Mecca in 1943, after going to Samarinda, because of a fire accident in 1931.

If the data was analyzed carefully, Abul Hasan's contribution to Islamic education has its own characteristics that were different from previous Banjar Ulama. Abul Hasan began to touch formal educational institutions, namely pioneering the establishment of the Madrasah Ahlussunah School. In the early 1900s, the existence of formal education 
was still rare, especially Islamic educational institutions. Madrasahs began to exist politically in Indonesia thanks to the struggle of the Ministry of Religion which was founded on January 3, 1946 (Drajat, 2018). In further developments, historically, the birth of madrasah was a sign of the emergence of the modern Islamic education system (Solihin, 2018).

Abdullah Marisie continued the next development of Islamic scholars from Banjar. Based on the results of interviews and supported by various sources, Abdullah Marisie moved to Samarinda in 1918. Like other Banjar Ulama, Abdullah Marisie also educated the public through Majelis Ta'lim in mosques, houses and mushalla. On the other hand, Abdullah Marisie also had a strategic position, namely as the imam of the mosque and the cleric IV until 1959 AD. As the imam of the mosque, Abdullah Marisie had a strategic role in education and da'wah, especially in improving awareness of the people in religion. It was following the research results of Moh. Arisal stated that mosque imams have a very high influence in increasing awareness of religious activities (Arisal, 2020). As the imam of the mosque, Abdullah Marisie managed the mosque with effective and efficient management which referred to the principles of modern management. In the field of education, Abdullah Marisie's contributions were quite a lot, such as establishing the first al-Islamiyah al-Syafiiyah Madrasa in Samarinda (1946), establishing the Religious Teacher Education (PGA, in 1958), and the IAIN Preparatory School in Samarinda (1963). His contribution in the field of education was not limited to pioneering, but also an educator according to his scientific fields, namely theology, morals, and Sufism.

In politics and government, Abdullah Marisie was a member of the DPR (Legislative Assembly) when the Kutai government was first formed. In the socioreligious field, Abdullah Marisie made a significant contribution, namely establishing the Nahdlatul Ulama organization together with his colleague, Abdul Hamid Kadir. Seeing Abdullah Marisie's progress in the field of education proved that Abdullah Marisie was a scholar who had a serious concern for Islamic education. The educational institution initiated by Abdullah Marisie had an important meaning in the development of Islamic education in Samarinda, including IAIN Samarinda. Abdullah Marisie's contribution experienced a development, namely reaching to formal education. Looked closely, Abdullah Marisie was a scholar who has various roles, namely as a scholar-intellectual, educator, activist, and also a politician. In the discourse of Muslim intellectuals in Indonesia, Abdullah Marisie was part of the foremost group in socio-politics with a background in Islamic boarding school education (Niam, 2010).

After Abdullah Marisie died, the Banjar Ulama struggle was then continued by Dja'far Sabran. Dja'far Sabran was born in 1920 in Paliwara Amuntai, South Kalimantan. Dja'far Sabran's education was initially pursued at Madrasah Rasyidiyah South Kalimantan starting from Ibtidaiyah, Tsanawiyah and Aliyah between 1931-1939. Dja'far Sabran studied with some of the great Ulama of South Kalimantan, including learning Sufism from Tuan Guru Khalid at Tangga Ulin Amuntai, Language knowledge (Arabic) was obtained from Abdur Rasyid in Pekapuran Amuntai. To finalize the knowledge of Arabic, Dja'far Sabran studied with Guru Zuhri at Tangga Ulin Amuntai. His jurisprudence 
was studied with two teachers, namely Arsyad at Tangga Ulin and Dakhlan in Long Bangkai Amuntai, while the science of Theology was taught at Tangga Ulin Amuntai. Less satisfied studying in his homeland, Dja'far Sabran continued his studies at Gontor Ponorogo (1939-1942) (Noorthaibah, 2010). Although Dja'far Sabran was educated at Pesantren Gontor, his field of study, after graduation, was Sufism. It proved that education in his hometown had more influenced his attitude and personality, especially in his scientific development.

Then in 1952 Dja'far Sabran moved to Samarinda. His motive for moving was due to preaching and economic development. Initially, Dja'far Sabran's activities were no different from those of his predecessor Banjar Ulama, namely that they were active in Majelis Ta'limin various places, namely in mosques, langgar, houses. For example, the regular Saturday and Sunday Majelis Ta'lim at Karang Mumus at Abdul Ghani's house, routine teaching at At-Taqwa, Raya Darussalam, and the Baiturrahim Mosques in Sungai Pinang Samarinda.

In the field of education, Dja'far Sabran pioneered the establishment of the Islamic Normal Madrasa with Hamri Haz in 1961. Then in 1968 he founded Madrasah Takhassus Diniyah. The establishment of Takhassus aimed to educate Islamic teachers to have adequate competence. Dja'far Sabran was a prolific person who wrote books. Among his works are Tarjamah Maulid Diba, 99 Gems of Hadith, Syair Isra 'Mi'raj, Syairs of the Prophet Yusuf-Zulaiha, Tahlil and Talqin, Overview of the characteristics of 20 Chair verses (Ayat Kursi), Treatise of Prayer I and II, Tarjamah Burdah, Risalah Tauhid, Salawat Kamilah and Prayer Arasy and others. Especially in the field of Sufism, Dja'far Sabran wrote the book Miftahul Ma'rifah, Sabilul Ma'rifah and Ainul Ma'rifat (Noorthaibah, 2010).

Dja'far Sabran has its own specifications in contributing to education in Samarinda. His contributions were through speech, activity, and writing. This writing skill was what distinguishes Dja'far Sabran's contribution from other Banjar Ulama. With his work, it showed that Dja'far Sabran, as an educator in Samarinda had a high intellectual level. His contribution was not limited to establishing a madrasah but with him as a prolific writer. The contribution given can be aligned with Ahmad Hasan from Bangil, who contributed to education through his activities and writing (Hizbullah, 2014).

The next Banjar Ulama who contributed to Samarinda was Asli Husaini. Asli Husain moved to Samarinda to develop Islam. He received information from his colleagues that in Samarinda there were a shortage of Human Resources, especially religious teachers. Armed with this information, Asli Husaini left for Samarinda. His activities in Samarinda were not much different from other Banjar Ulama, namely educating the community through religious assemblies (Majelis Ta'lim) in mosques, langgar and homes. In the field of education, Asli Husaini founded pesantren Darul Ihsan in 1978 and was inaugurated by the Governor of East Kalimantan, Abdul Wahab Syahrani, in 1979. The pesantren that was founded by Asli Husaini was the first Islamic boarding school in Samarinda and had an important meaning in educating the nation's children, especially in Samarinda. Over time, even though pesantren were founded on community initiatives, they were able to 
maintain their independence even though many educational institutions of Dutch heritage were nationalized (Pohl, 2012).

Looking at the characteristics of the contribution of Banjar Ulama in Samarinda, it can be mapped that Tayyib Babussalam and Abdul Khalid tend to preserve traditional values by maintaining local traditions. Abdullah Marisie tended to be traditionalprofessional in Islamic development, while Ja'far Sabran was more of a traditionalintellectual type of organic Ulama. This mapping was similar to Choirul Mahfud's findings that characteristics of the contribution of contemporary Ulama in Indonesia were an Ulama who has an organic role with movements that are global, local, traditional, professional and intellectual (Mahfud, 2020).

The movement and thought of Banjar Ulama can not be separated from its senior Ulama, namely Muhammad Arsyad al-Banjari, which was to develop classical treasures and expand the institution of Islamic education. In a broader context at the same time, the movement and thought of Banjar Ulama in sync with the movement and thought of Javanese Ulama such as Wahab Hasbullah, Bisri Syansuri and others. Based on the description above, the contribution of Banjar Ulama in the field of education is very diverse. It was in accordance with the educational background and social conditions of the community. The following was the contribution of the Banjar Ulama in tabular form.

Table 1: Contribution of the Banjar Ulama in the Education Sector

\begin{tabular}{lll}
\hline NO & NAME & CONTRIBUTION \\
\hline 1 & Tayyib Babussalam & 1. Establishing Majelis Ta'lim \\
& 2. Building Jami' Mosque \\
& 3. Imam of the Mosque \\
& 4. Teacher in various Majelis Ta'lim \\
& 5. The First Cleric (Penghulu I) \\
& 6. Landrat Chairman of the Islamic Religion \\
\hline 2 & Abdul Khalid & 1. Developing Majelis Ta'lim \\
& 2. Imam of the Masjid \\
& 3. The Second Cleric (Penghulu II) \\
& 4. Teacher in several Majelis Ta'lim \\
\hline 3 & 1. Established Madrasah Ahlussunah School \\
& 2. Imam of Jami' Mosque \\
& 3. Founding Majelis Ta'lim \\
& 4. The Third Cleric (Penghulu III) \\
\hline 4 & 1. Founded the First Madrasah Syafiiyah \\
& 2. Established 'PGA' in Samarinda \\
& 3. Established IAIN preparatory school \\
& 4. Grand Imam of Jami' Mosque \\
& 5. Managing the Mosque assemblies in a modern \\
& 6ay \\
& 6. Established Nahdlatul Ulama \\
& 7. The Fourth Cleric (Penghulu IV)
\end{tabular}




\begin{tabular}{lll}
\hline 5 & Dja'far Sabran & 1. Founded a Normal Islamic Madrasah \\
& & 2. Write books \\
& 3. Teacher in various Majelis Ta'lim \\
\hline 6 & Asli Husain & 1. Founded the first pesantren in Samarinda \\
& 2. Teacher in various Majelis Ta'lim
\end{tabular}

The table above reflects that the existence of Banjar Ulama had a very real contribution in Samarinda. On the other hand, the existence of Banjar Ulama was influential in religious patterns and traditions in Samarinda. It was because most of the Ulama in Samarinda had a very strong network with the Ulama of Banjarmasin in South Kalimantan, especially the scientific and geographical networks (Khojir, 2016).

\section{CONCLUSION}

Based on the results of the research and data analysis, it can be concluded that the Banjar Ulama who lived in Samarinda have a very real contribution to the field of Islamic education. These contributions were: First, establishing non-formal education in the form of Majelis Ta'lim in various areas of Samarinda. Second, functioning the mosque as a community education centre (congregation). Third, establishing formal education, namely madrasas. Fourth, establishing an Islamic Higher Education Preparatory School. Fifth, establishing the first Islamic boarding school in Samarinda. Also, Banjar Ulama contributed to the field of socio-religious organization and government. In the socioreligious organization established Nahdlatul Ulama and in the government sector became the leader who took care of matters of religious life. These contributions have had a positive impact on the development of Islamic education in Samarinda. Noting the above conclusions, the authors suggest that further research should be carried out, namely the Contribution of Ulama from Banjar Descent in education, which is the second generation of Banjar people, in the development of Islamic education in Samarinda.

\section{REFERENCES}

A'la, A., Mukarrom, A., \& Zamzami, M. (2018). Kontribusi Aliansi Ulama Madura (AUMA) dalam Merespons Isu Keislaman dan Keumatan di Pamekasan Madura. Religió: Jurnal Studi Agama-Agama, 8(2), 227-255. https://doi.org/10.15642/religio.v8i2.793.

Abidin, M. Z. (2018). Ulama in Indonesian Urban Society: A View of Their Role and Position in the Change of Age. Jurnal Theologia. https://doi.org/10.21580/teo.2017.28.2.1863.

Akmal, A. M. (2018). Konsepi Ulama dalam Alquran. Ash-Shahabah, 4(2), 174-182. https://journal-uim-makassar.ac.id/index.php/ASH/article/view/225.

Akmaliah, W. (2014). When Ulama support a pop singer: Fatin Sidqiah and Islamic pop culture in post-Suharto Indonesia. Al-Jami'ah: Journal of Islamic Studies, 52(2), 351-373. https://doi.org/https://doi.org/10.14421/ajis.2014.522.351-373.

Al-Krenawi, A. (2016). The Role of the Mosque and its Relevance to Social Work. International Social Work, 59(3). https://doi.org/10.1177/0020872815626997. 
Alamsyah, Mahmudah, S., \& Huda, S. (2020). The Contextualization of Hadith in Indonesia: Nusantara Ulema's Response to Islamists. International Journal of Psychosocial Rehabilitation, 24(7), 1548-1558. http://repository.iainkediri.ac.id/121/.

Arisal, M. (2020). Pengaruh Imam Desa Dalam Peningkatkan Kesadaran Beragama Masyarakat Di Kec. Libureng Kab. Bone. AL-Qayyimah: Jurnal Pendidikan Islam, 2(2), 122-130. file:///C:/Users/PC/Downloads/657-1840-1-SM.pdf.

Arnawati, A. (2017). Kedudukan Dan Peran Ulama Dalam Perspektif Alquran (Studi Komparatif Tafsīr al-Qur'ān al-'Azīm dan Tafsīr Fī Zilāl al- Qur'ān. Al-Fath. https://doi.org/http://dx.doi.org/10.32678/alfath.v11i1.875.

As' ad, M. (2016). Masjid Tua Shirathal Mustaqiem Samarinda: Fenomena Dahsyatnya Kekuatan Spiritual. Al-Qalam, 19(2), 265-274. https://doi.org/http://dx.doi.org/10.31969/alq.v19i2.161.

Awaluddin, A. (2020). Islamic Education Thought of Kh. Muhammad Kholil Bangkalan and It's Implementation on Contemporary Generation. At-Tarbawi: Jurnal Kajian Kependidikan Islam, 5(1). https://doi.org/10.22515/attarbawi.v5i1.2227.

Basyari, F. M. (2018). Contribution of Indonesian Ulama Council for the Aplication Islamic Law in Indonesia. Journal of Islamicate Studies, 1(1). https://doi.org/https://doi.org/10.32506/jois.v1i1.436.

Bein, A. (2012). Ottoman Ulema, Turkish Republic: Agents of Change and Guardians of Tradition. American Historical Review, 212. https://www.amazon.com/OttomanUlema-Turkish-Republic-Guardians-ebook/dp/B005VREV08.

Djafaara, S. (2020). Polemik Munasabah Sebagai Metode Kajian Tafsir (Kajian Metodolgi $\begin{array}{llll}\text { Tafsir Ulama } \quad \text { Klasik). } & \text { 6L-Asas, }\end{array}$ https://ejournal.iainpalopo.ac.id/index.php/alasas/article/view/1647.

Drajat, M. (2018). Sejarah Madrasah Di Indonesia. Journal for Islamic Studies, 1(1), 1920206. https://doi.org/10.5281/zenodo.1161729.

Fathurrahman. (2015). Masjid Sebagai Pusat Pendidikan Islam Masa Klasik. Jurnal Ilmiah "Kreatif," 12(1), 1-12. file:///C:/Users/PC/Downloads/Documents/72-Article Text-187-1-10-20180504.pdf.

Gusmawati, G. (2015). Islamisasi di Kerajaan Kutai pada Awal Abad Ke-17 (Suatu Tinjauan Historis). Makassar: Universitas Islam Negeri Alauddin Makassar.

Hanafi, H. (2017). Genealogi Kajian Hadis Ulama al-Banjari. Millati: Journal of Islamic $\begin{array}{lll}\text { Studies } \text { and } & \text { Humanities, }\end{array}$ https://doi.org/https://doi.org/10.18326/mlt.v2i2.169-194.

Hartati, Z. (2012). Peranan Kyai Haji Ibrahim Dalam Dakwah dan Pendidikan. Al-Banjari: Jurnal Ilmiah Ilmu-Ilmu Keislaman, https://doi.org/http://dx.doi.org/10.18592/al-banjari.v11i2.427.

Hasnida, H. (2017). Sejarah Perkembangan Pendidikan Islam di Indonesia pada Masa PRA Kolonialisme dan Masa Kolonialisme (Belanda, Jepang, Sekutu). Kordinat/ Jurnal Komunikasi Antar Perguruan Tinggi Agama Islam, 16(2), 237-256. https://doi.org/10.15408/kordinat.v16i2.6442.

Helim, A. (2017). Poligami Perspektif Ulama Banjar. Islamica: Jurnal Studi Keislaman, 12(1), 50-79. http://digilib.iain-palangkaraya.ac.id/id/eprint/1338.

Hizbullah, N. (2014). Ahmad Hasan : Kontribusi Ulama dan Pejuang Pemikiran Islam di Nusantara dan Semenanjung Melayu. Buletin Al-Turas. 
https://doi.org/https://doi.org/10.15408/bat.v20i2.3761.

Iderus, M. H. S. (2016). Peranan Ulama Banjar Abad Ke-20 Dalam Tradisi Penulisan Hadis Arba'în di Banjar dan Malaysia. Al-Banjari: Jurnal Ilmiah Ilmu-Ilmu Keislaman, 15(2), 147-164.

Jadidah, A. (2016). Paradigma Pendidikan Alternatif: Majelis Taklim Sebagai Wadah Pendidikan Masyarakat. Jurnal Pusaka, 4(1), 27-42. http://ejournal.alqolam.ac.id/index.php/jurnal_pusaka/article/view/majelistaklim-sbg-wadah-pendidikan.

Julaiha, S. (2016). Peran Ulama Keturunan Banjar dalam Berdakwah di Kota Samarinda. Repositori Perpustakaan UIN Antasari Banjarmasin. http://idr.uinantasari.ac.id/id/eprint/6261.

Khaerani, A. (2015). Tuan Tunggang Parangan dan Islamisasi di Kerajaan Kutai Kalimantan Timur. Kalimantan.

Khojir, K. (2016). The Pesantren Network in Samarinda. Jurnal Pendidikan Islam, 5(2). https://doi.org/10.14421/jpi.2016.52.213-233.

Mahfud, C. (2020). Imagined Islamic Societies and the Role of Ulema in Contemporary Indonesia. AKADEMIKA: Jurnal Pemikiran Islam, 24(2), 269-278. https://doi.org/https://doi.org/10.32332/akademika.v24i2.1567.

Makmur, A. (2012). Peranan Ulama Dalam Membina Masyarakat Banjar di Kalimantan Selatan. MIQOT: Jurnal Keislaman. https://doi.org/10.30821/miqot.v36i1.114.

Mujiburrahman, \& Abidin, M. Z. (2012). Ulama Banjar Kharismatik Masa Kini di Kalimantan Selatan: Studi terhadap Figur Guru Bachiet, Guru Danau, dan Guru Zuhdi. Al-Banjari: Jurnal Ilmiah Ilmu-Ilmu Keislaman, 11(2). https://doi.org/http://dx.doi.org/10.18592/al-banjari.v11i2.421.

Niam, K. (2010). The Discourse of Muslim Intellectuals and Ulama'in Indonesia: A Historical Overview. Journal of Indonesian Islam, 4(2), 287-316. https://doi.org/10.15642/JIIS.2010.4.2.287-316.

Noor, M. F. (2016). Kerajaan Kutai Kartanegara Ing Martadipura dan peran raja dalam pengembangan agama Islam di Kerajaan Kutai abad ke-17 dan 18. Surabaya: UIN Sunan Ampel Surabaya.

Noor, Y., \& Sayyidati, R. (2018). Peranan Tuan Guru Haji Muhammad Kasyful Anwar dan Tuan Haji Setta dalam Mendirikan Pesantren Darussalam Martapura, Kabupaten Banjar, Kalimantan Selatan, 1924. JUSPI (Jurnal Sejarah Peradaban Islam), 2(2), 210-224. https://doi.org/http://dx.doi.org/10.30829/j.v2i2.3037.

Noorthaibah. (2010). Pemikiran Tasawuf K.H. Dja'far Sabran (I). Samarinda: P3M IAIN Samarinda.

Nur, A. (2013). Kontribusi dan Peran Ulama Mencegah Hadits Maudhu '. An-Nida'. http://ejournal.uin-suska.ac.id/index.php/Anida/article/view/334/317.

Pohl, F. (2012). Islamic Education and Civil Society: Reflections on the Pesantren Tradition in Contemporary Indonesia. Comparative and International Education Society (CIES), 50(3). https://doi.org/https://doi.org/10.1086/503882.

Rozali, M. (2017). Kontribusi Syaikh Hasan Maksum dalam Bidang Pendidikan di Sumatera Utara. JUSPI (Jurnal Sejarah Peradaban Islam), 1(2), 277-288. https://doi.org/10.30829/j.v1i2.1208. 
Samsir, S. (2019). Masuk dan Berkembangnya Islam di Kerajaan Kutai Kartanegara. Ri'ayah: Jurnal Sosial Dan Keagamaan, 3(02), 30-42. https://doi.org/https://doi.org/10.32332/riayah.v3i02.1318.

Sattar, A. (2014). Badan Silaturrahmi Ulama Madura (BASRA): Dakwah Multi Fungsi. Jurnal Komunikasi Islam, https://doi.org/https://doi.org/10.15642/jki.2014.4.2.\%25p.

Solihin, I. (2018). Madrasah dan Pertumbuhan Keilmuan Dunia Islam: Sebuah Kajian Sosio-Historis. Elementary: Jurnal Ilmiah Pendidikan Dasar, 4(1), 97-106. https://doi.org/https://doi.org/10.32332/elementary.v4i1.1080.

Sukarni, S. (2015). Kitab Fikih Ulama Banjar: Kesinambungan Dan Perubahan Kajian Konsep Fikih Lingkungan. Analisis: Jurnal Studi Keislaman, 15(2), 433-472. https://doi.org/https://doi.org/10.24042/ajsk.v15i2.731.

Tasa, R. (2010). Kilas Sejarah Masjid Sirathal Mustaqiem Samarinda. Samarinda: Pemerintah Kota Samarinda Bekerjasama dengan Bisa Advertising.

Winarni, L. (2014). The Political Identity of Ulama in the 2014 Indonesian Presidential Election. Al-Jami'ah: Journal of Islamic Studies, 52(2), 257-269. https://doi.org/https://doi.org/10.14421/ajis.2014.522.257-269. 